\title{
KEEFEKTIFAN MEDIA LAPTOP SI UNYIL DALAM PEMBELAJARAN TEKS PROSEDUR KOMPLEKS
}

\author{
Roni Sulistiyono \\ Pendidikan Bahasa dan Sastra Indonesia \\ Fakultas Keguruan dan Ilmu Pendidikan \\ Universitas Ahmad Dahlan \\ Roni.sulistiyono@pbsi.uad.ac.id
}

Naskah diterima: 12 Oktober 2017; direvisi: 12 Oktober 2017; disetujui: 28 November 2017

\begin{abstract}
Creative educators are educators who are able to utilize the media around as a means of learning. One of the television shows that can be utilized as a complex text learning media is a show of Laptop Si Unyil. The impression is about the process of making something or the use of the tool described in a coherent manner. Based on the results of experiments on students PBSI, FKIP, UAD, this show is able to provide better learning outcomes to the group taught by using media Si Unyil Laptop. It can be proved by t-test among groups. Based on posttest data of experimental group and control group obtained t count equal to 2,575 with indigo df equal to 43 and value $p=0,012$ at significance level 0,05 (5\%). The $p$ value <from the significance level is 0.05 (0.012 <0.05). Impressions Siy Unyil laptop is able to provide effectiveness in learning the text of complex procedures on students PBSI, FKIP, UAD who are following the lecture of Indonesian Language. This is evidenced from the calculation of t-test data pretest and posttest in the experimental group obtained the result that the value of $t$ arithmetic -3.924 denagan value $d f 42$ and significance 0.000 . Result of t-test of pretest and posttest data in experiment group obtained $p$ value smaller than significance level 0,05 (0,000<0,05).
\end{abstract}

Keywords: Effectiveness, Laptop Si Unyil, text of complex procedures

\begin{abstract}
ABSTRAK
Pendidik yang kreatif adalah pendidik yang mampu memanfaatkan media yang ada di sekitar sebagai sarana dalam pembelajaran. Salah satu tayangan televisi yang dapat dimanfaatkan sebagai media pembelajaran teks prosedur kompleks adalah tayangan Laptop Si Unyil. Tayangan tersebut berisi tentang proses pembuatan sesuatu atau penggunaan alat yang dijelaskan secara runtut. Berdasarkan hasil eksperimen terhadap mahasiswa PBSI, FKIP, UAD, tayangan ini mampu memberikan hasil pembelajaran yang lebih baik kepada kelompok yang diajar dengan menggunakan media Laptop Si Unyil. Hal itu dapat dibuktikan dengan uji-t antarkelompok. Berdasar data posttest kelompok eksperimen dan kelompok kontrol diperoleh $\mathrm{t}$ hitung sebesar $-2,575$ dengan nila df sebesar 43 dan nilai $p=$ 0,012 pada taraf signifikansi $0,05(5 \%)$. Nilai $p<$ dari taraf signifikansi $0,05(0,012<0,05)$. Tayangan Laptop Si Unyil ini mampu memberikan keefektifan dalam pembelajaran teks prosedur kompleks pada mahasiswa PBSI, FKIP, UAD yang sedang mengikuti perkuliahan Pembelajaran Bahasa Indonesia. Hal itu dibuktikan dari perhitungan uji-t data pretest dan posttest pada kelompok eksperimen diperoleh hasil bahwa nilai $t$ hitung $-3,924$ dengan nilai df 42 dan signifikasi 0,000. Hasil uji-t data pretest dan posttest pada kelompok eksperimen diperoleh nilai $p$ lebih kecil dari taraf signifikansi $0,05(0,000<0,05)$.
\end{abstract}

Kata kunci: Keefektifan, Laptop Si Unyil, teks prosedur kompleks 


\section{PENDAHULUAN}

Sebagai seorang pendidik, dosen harus berperan sebagai fasilitator, yaitu memfasilitasi kegiatan belajar mahasiswanya. Agar mahasiswa terfasilitasi belajarnya, maka salah satu keterampilan yang harus dimiliki dosen adalah keterampilan mengadakan variasi dalam kegiatan pembelajaran, misalnya variasi dalam memilih strategi, pendekatan, metode, teknik, dan media dalam pembelajaran. Semua itu bertujuan agar pembelajaran menjadi aktif yang artinya mampu mengaktifkan mahasiswa untuk aktif mencari tahu, bukan aktif diberi tahu. Hal itu sependapat dengan Sanjaya (2012: 23) bahwa sebagai fasilitator dalam pembelajaran, pendidik berperan dalam memberikan pelayanan untuk memudahkan peserta didik dalam kegiatan pembelajaran.

Salah satu permasalahan yang tidak dilakukan oleh dosen dalam pembelajaran adalah keterampilan menggunakan media pembelajaran. Media yang dipakai hanyalah materi yang ada dalam powerpoint. Apabila setiap saat dosen hanya memanfaatkan powerpoint dalam kegiatan pembelajarannya, maka jangan salah apabila mahasiswa bosan mengikuti pembelajaran. Padahal apabila dosen memiliki kreativitas dalam menggunakan media, maka dosen bisa membuatnya sendiri atau memanfaatkan media yang ada di sekitarnya, misalnya tayangan televisi.

Salah satu tayangan televisi yang dapat digunakan dalam pembelajaran adalah tayangan trans-7 yang berjudul Laptop $\mathrm{Si}$ Unyil. Tayangan ini dapat dijadikan media pembelajaran Bahasa Indonesia, yaitu teks prosedur kompleks (Sulistiyono, 2016: 869). Hal itu dikarenakan dalam tayangan Laptop Si Unyil menceritakan tentang proses pembuatan sesuatu secara runtut, misalnya tayangan pada tanggal 18 Mei 2017 berisi tentang proses pembuatan aneka kuliner laut (http://m.youtube.com/watch?v=Jxq0DCW 7laU).

Teks prosedur kompleks merupakan salah satu materi yang diajarkan dalam mata kuliah Pembelajaran Bahasa Indonesia. Teks prosedur kompleks adalah teks yang memberikan petunjuk untuk melakukan atau menggunakan sesuatu dengan langkah-langkah yang urut (Priyatni, 2015: 87). Hal itu senada dengan pendapatnya Kosasih (2014: 67-68) bahwa teks prosedur kompleks adalah teks yang menjelaskan langkah-langkah secara lengkap, jelas, dan terperinci tentang cara melakukan sesuatu serta berkenaan dengan penggunaan alat secara urut. Teks prosedur kompleks memiliki struktur yang berbeda dengan jenis teks lainnya, yaitu tujuan dan langkah-langkah menggapai tujuan tersebut. Yang dimaksud dengan tujuan adalah hasil akhir yang akan dicapai. Sementara langkah-langkah adalah cara yang ditempuh untuk mencapai tujuan (Maryanto, dkk., 2013: 44).

Untuk mengetahui keefektifan media Laptop Si Unyil dalam pembelajaran teks prosedur kompleks perlu dilakukan penelitian eksperimen. Penelitian eskperimen ini dilakukan pada mahasiswa PBSI, FKIP, UAD yang sedang mengikuti perkuliahan Pembelajaran Bahasa Indonesia. Oleh karena itu, tujuan penelitian ini adalah untuk mengetahui perbedaan kemampuan memahami dan memproduksi teks prosedur kompleks antara kelompok yang diajar dengan menggunakan media Laptop Si Unyil dengan kelompok yang diajar tanpa menggunakan media Laptop Si Unyil dan untuk mengetahui keefektifan penggunaan media Laptop Si Unyil dalam pembelajaran teks prosedur kompleks pada mahasiswa PBSI, FKIP, UAD yang sedang mengikuti mata kuliah Pembelajaran Bahasa Indonesia.

\section{METODE PENELITIAN}

Penelitian ini termasuk penelitian eksperimen dengan populasi mahasiswa PBSI, FKIP, UAD dan sampel penelitiannya adalah mahasiswa semester IV yang sedang mengikuti perkuliahan Pembelajaran Bahasa Indonesia tahun akademik 2016/2017. Pengambilan sampel 
dalam penelitian ini menggunakan teknik purposive sampling, yaitu kelas A sebagai kelompok eksperimen, sedangkan kelas D sebagai kelompok kontrol. Kelas A menggunakan media Laptop Si Unyil dalam pembelajaran teks prosedur kompleks, serta kelas D menggunakan media buku teks. Instrumen yang digunakan adalah tes, yaitu tes kemampuan memahami dan memproduksi teks prosedur kompleks. Selanjutnya data dianalisis menggunakan statistik deskriptif dan statistik inferensial dengan menggunakan program SPSS versi 22.

\section{HASIL DAN PEMBAHASAN}

\section{Deskripsi Data}

a. Data Pretest Pembelajaran Teks Prosedur Kompleks Kelompok Kontrol

Kelompok kontrol merupakan kelompok yang melaksanakan pembelajaran teks prosedur kompleks tanpa menggunakan media Laptop Si Unyil. Sebelum melaksanakan pembelajaran teks prosedur kompleks, kelompok ini diberi pretest tentang kemampuan memahami dan memproduksi teks prosedur kompleks.

Berdasarkan hasil pretest terhadap kelompok kontrol diperoleh skor tertinggi 90 dan skor terendah 40. Skor rerata (mean) sebesar 63,67 dan standar deviasi (std. deviation) sebesar 13,540. Hasil perhitungan skor pretest kelompok kontrol dapat dilihat pada tabel berikut.

Tabel 1. Distribusi Frekuensi Pretest Pembelajaran Teks Prosedur Kompleks Kelompok Kontrol

\begin{tabular}{cccc}
\hline Skor & Frekuensi & $\begin{array}{c}\text { Persen } \\
(\%)\end{array}$ & $\begin{array}{c}\text { Frekuensi } \\
\text { Komulatif }\end{array}$ \\
\hline 40 & 1 & 2.3 & 1 \\
\hline 45 & 4 & 9.3 & 5 \\
\hline 47 & 1 & 2.3 & 6 \\
\hline 50 & 5 & 11.6 & 11 \\
\hline 55 & 4 & 9.3 & 15 \\
\hline 58 & 1 & 2.3 & 16 \\
\hline 60 & 3 & 7.0 & 19 \\
\hline 64 & 2 & 4.7 & 21 \\
\hline 65 & 7 & 16.3 & 28 \\
\hline
\end{tabular}

\begin{tabular}{cccc}
\hline 70 & 4 & 9.3 & 32 \\
\hline 75 & 3 & 7.0 & 35 \\
\hline 80 & 4 & 9.3 & 39 \\
\hline 85 & 1 & 2.3 & 40 \\
\hline 90 & 3 & 7.0 & 43 \\
\hline Total & 43 & 100.0 & \\
\hline
\end{tabular}

Berdasarkan nilai pretest yang diperoleh pada kemampuan memahami dan memproduksi teks prosedur kompleks kelompok kontrol diperoleh hasil bahwa 28 mahasiswa (65\%) memperoleh nilai di bawah 70. Sementara mahasiswa yang memperoleh nilai di atas 70 ada 15 mahasiswa atau 35\%. Berdasarkan data tersebut dapat disimpulkan bahwa nilai pretest kelompok kontrol belum memperoleh ketuntasan karena nilai ketuntasan yang ditetapkan adalah $70 \%$ mahasiswa memiliki nilai $>70$. Permasalahan yang ditemukan adalah rendahnya pemahaman mahasiswa terhadap teks prosedur kompleks, penggunaan bahasa, dan kesalahan struktur kalimat.

\section{b. Data Pretest Pembelajaran Teks Prosedur Kompleks Kelompok Eksperimen}

Kelompok eksperimen merupakan kelompok yang melaksanakan pembelajaran teks prosedur kompleks dengan menggunakan media Laptop Si Unyil. Sebelum melaksanakan pembelajaran teks prosedur kompleks, kelompok ini diberi pretest tentang kemampuan memahami dan memproduksi teks prosedur kompleks.

Berdasarkan hasil pretest terhadap kelompok eksperimen diperoleh skor tertinggi 93 dan skor terendah 42. Skor rerata (mean) sebesar 67,26 dan standar deviasi (std. deviation) sebesar 13,565. Hasil perhitungan skor pretest kelompok eksperimen dapat dilihat pada tabel berikut. 
Tabel 2. Distribusi Frekuensi Skor

Pretest Pembelajaran Teks

Prosedur Kompleks Kelompok Eksperimen

\begin{tabular}{cccc}
\hline Skor & Frekuensi & $\begin{array}{c}\text { Persen } \\
(\%)\end{array}$ & $\begin{array}{c}\text { Frekuensi } \\
\text { Komulatif }\end{array}$ \\
\hline 42 & 1 & 2.3 & 1 \\
\hline 48 & 1 & 2.3 & 2 \\
\hline 50 & 3 & 7.0 & 5 \\
\hline 52 & 2 & 4.7 & 7 \\
\hline 55 & 3 & 7.0 & 10 \\
\hline 56 & 2 & 4.7 & 12 \\
\hline 58 & 3 & 7.0 & 15 \\
\hline 60 & 3 & 7.0 & 18 \\
\hline 66 & 1 & 2.3 & 19 \\
\hline 67 & 1 & 2.3 & 20 \\
\hline 68 & 5 & 11.6 & 25 \\
\hline 70 & 3 & 7.0 & 28 \\
\hline 72 & 2 & 4.7 & 30 \\
\hline 75 & 2 & 4.7 & 32 \\
\hline 76 & 1 & 2.3 & 33 \\
\hline 78 & 2 & 4.7 & 35 \\
\hline 83 & 1 & 2.3 & 36 \\
\hline 85 & 3 & 7.0 & 39 \\
\hline 92 & 2 & 4.7 & 41 \\
\hline 93 & 2 & 4.7 & 43 \\
\hline Total & 43 & 100.0 & \\
\hline & & &
\end{tabular}

Berdasarkan nilai pretest yang diperoleh pada kemampuan memahami dan memproduksi teks prosedur kompleks kelompok eksperimen diperoleh hasil sebagai berikut. Mahasiswa yang memperoleh nilai kurang dari 70 ada 25 mahasiswa (58\%). Sementara mahasiswa yang memperoleh nilai di atas 70 ada 18 mahasiswa $(42 \%)$. Berdasarkan data tersebut dapat disimpulkan bahwa nilai pretest kelompok eksperimen belum memperoleh ketuntasan karena nilai ketuntasan yang ditetapkan adalah $70 \%$ mahasiswa memiliki nilai $>70$. Permasalahan yang ditemukan adalah rendahnya pemahaman akan teks prosedur kompleks, penggunaan bahasa, dan struktur kalimat.

\section{c. Data Posttest Pembelajaran Teks Prosedur Kompleks Kelompok Kontrol}

Berdasarkan hasil posttest terhadap kelompok kontrol diperoleh skor tertinggi 90 dan skor terendah 40. Skor rerata (mean) sebesar 66,33 dan standar deviasi (std. deviation) sebesar 11,322. Hasil perhitungan skor pretest kelompok kontrol dapat dilihat pada tabel berikut.

\section{Tabel 3. Distribusi Frekuensi Skor Posttest Pembelajaran Teks Prosedur Kompleks Kelompok Kontrol}

\begin{tabular}{cccc}
\hline Skor & Frekuensi & Persent & $\begin{array}{c}\text { Frekuensi } \\
\text { Komulatif }\end{array}$ \\
\hline 40 & 1 & 2.3 & 1 \\
\hline 45 & 1 & 2.3 & 2 \\
\hline 46 & 1 & 2.3 & 3 \\
\hline 50 & 1 & 2.3 & 4 \\
\hline 52 & 3 & 7.0 & 7 \\
\hline 55 & 3 & 7.0 & 10 \\
\hline 56 & 2 & 4.7 & 12 \\
\hline 63 & 1 & 2.3 & 13 \\
\hline 64 & 3 & 7.0 & 16 \\
\hline 65 & 1 & 2.3 & 17 \\
\hline 67 & 2 & 4.7 & 19 \\
\hline 68 & 5 & 11.6 & 24 \\
\hline 70 & 3 & 7.0 & 27 \\
\hline 72 & 5 & 11.6 & 32 \\
\hline 74 & 1 & 2.3 & 33 \\
\hline 78 & 8 & 18.6 & 41 \\
\hline 86 & 1 & 2.3 & 42 \\
\hline 90 & 1 & 2.3 & 43 \\
\hline Total & 43 & 100.0 & \\
\hline & & &
\end{tabular}

Berdasarkan nilai yang diperoleh melalui posttest kegiatan memahami dan memproduksi teks prosedur kompleks pada kelas kontrol setelah dijelaskan materi oleh dosen serta media buku teks diperoleh hasil sebagai berikut. Mahasiswa kelas kontrol yang memperoleh nilai kurang dari 70 ada 24 mahasiswa atau 56\%. Sementara mahasiswa yang memperoleh nilai di atas 70 ada 19 mahasiswa atau 44\%. Berdasarkan data tersebut dapat disimpulkan bahwa mahasiswa kelas 
kontrol belum memenuhi KKM, karena nilai KKM yang ditetapkan adalah $70 \%$ mahasiswa memiliki nilai $>70$. Permasalahan yang terjadi adalah kurangnya pemahaman akan struktur teks prosedur kompleks dan penulisan kalimat yang salah.

\section{d. Data Posttest Pembelajaran Teks Prosedur Kompleks Kelompok Eksperimen}

Berdasarkan hasil posttest terhadap kelompok eksperimen diperoleh skor tertinggi 98 dan skor terendah 40. Skor rerata (mean) sebesar 73,70 dan standar deviasi (std. deviation) sebesar 14,977. Hasil perhitungan skor posttest kelompok eksperimen dapat dilihat pada tabel berikut.

\section{Tabel 4. Distribusi Frekuensi Skor Posttest Pembelajaran Teks Prosedur Kompleks Kelompok Eksperimen}

\begin{tabular}{cccc}
\hline Skor & Frekuensi & $\begin{array}{c}\text { Persen } \\
(\%)\end{array}$ & $\begin{array}{c}\text { Frekuensi } \\
\text { Komulatif }\end{array}$ \\
\hline 40 & 1 & 2.3 & 1 \\
\hline 50 & 4 & 9.3 & 5 \\
\hline 52 & 1 & 2.3 & 6 \\
\hline 55 & 2 & 4.7 & 8 \\
\hline 58 & 2 & 4.7 & 10 \\
\hline 65 & 1 & 2.3 & 11 \\
\hline 67 & 1 & 2.3 & 12 \\
\hline 68 & 1 & 2.3 & 13 \\
\hline 70 & 5 & 11.6 & 18 \\
\hline 73 & 1 & 2.3 & 19 \\
\hline 74 & 1 & 2.3 & 20 \\
\hline 75 & 4 & 9.3 & 24 \\
\hline 76 & 1 & 2.3 & 25 \\
\hline 80 & 3 & 7.0 & 28 \\
\hline 82 & 2 & 4.7 & 30 \\
\hline 83 & 1 & 2.3 & 31 \\
\hline 85 & 3 & 7.0 & 34 \\
\hline
\end{tabular}

\begin{tabular}{cccc}
\hline 88 & 1 & 2.3 & 35 \\
\hline 90 & 3 & 7.0 & 38 \\
\hline 93 & 1 & 2.3 & 39 \\
\hline 95 & 2 & 4.7 & 41 \\
\hline 97 & 1 & 2.3 & 42 \\
\hline 98 & 1 & 2.3 & 43 \\
\hline Total & 43 & 100.0 &
\end{tabular}

Berdasarkan nilai posttest yang diperoleh melalui kegiatan memahami dan memproduksi teks prosedur kompleks setelah dosen menggunakan media Laptop Si Unyil diperoleh hasil sebagai berikut. Mahasiswa kelas eksperimen yang memperoleh nilai kurang dari 70 ada 13 mahasiswa atau 30\%. Sementara itu, mahasiswa yang memperoleh nilai di atas 70 ada 30 mahasiswa atau $70 \%$. Berdasarkan data tersebut dapat disimpulkan bahwa mahasiswa kelas eksperimen sudah memenuhi KKM karena nilai mahasiswa sudah $70 \%>70$. Meskipun demikian, permasalahan yang masih muncul adalah pada penulisan kalimat.

\section{Analisis Inferensial}

a. Uji Normalitas

Uji normalitas dilakukan dengan tujuan untuk mengetahui data yang diperoleh berasal dari data yang berdistribusi normal/tidak normal. Uji normalitas dalam penelitian ini menggunakan uji Kolmogorov Smirnov dengan bantuan SPSS versi 22 dengan kriteria jika nilai signifikansi $p>0,05$ maka dinyatakan berdistribusi normal, akan tetapi apabila nilai signifikansi $p<0,05$ maka data dinyatakan tidak berdistribusi normal. Hasil uji normalitas data dilakukan pada kelas eksperimen dan kelas kontrol, baik pretest maupun posttest. Berikut disajikan tabel perhitungan uji normalitas.

Tabel 5. Rangkuman Hasil Uji Normalitas Sebaran

\begin{tabular}{llccc}
\hline No & \multicolumn{1}{c}{ Data } & Kolmogorov-smirnov & $\mathrm{P}$ & Keterangan \\
\hline 1. & pretest kontrol & 0,112 & 0,200 & $\mathrm{p}>0,05=$ normal \\
\hline 2. & pretest eksperimen & 0,122 & 0,108 & $\mathrm{p}>0,05=$ normal \\
\hline 3. & posttest kontrol & 0,119 & 0,136 & $\mathrm{p}>0,05=$ normal \\
\hline 4. & posttest eksperimen & 0,128 & 0,072 & $\mathrm{p}>0,05=$ normal \\
\hline
\end{tabular}


Berdasarkan tabel di atas dapat dijelaskan bahwa hasil perhitungan data pretest kelompok kontrol diperoleh indeks Kolmogorov-Smirnov sebesar $\quad 0,112$ dengan $p=0,200$. Data pretest kelompok eksperimen diperoleh indeks KolmogorovSmirnov sebesar 0,122 dengan $p=0,108$. Data posttest kelompok kontrol diperoleh indeks Kolmogorov-Smirnov sebesar 0,119 dengan nilai $p=0,136$. Data posttest kelompok eksperimen diperoleh indeks Kolmogorov-Smirnov sebesar 0,128 dengan $p=0,072$. Dengan demikian, berdasarkan sebaran data pretest dan posttest pada kelompok kontrol dan kelompok eksperimen dapat dikatakan normal karena diperoleh nilai $p>0,05$.

\section{b. Uji Homogenitas Varian}

Uji homogenitas varian bertujuan untuk mengetahui sampel yang diambil berasal dari populasi yang memiliki varian yang sama dan tidak menunjukkan perbedaan yang signifikan satu dengan yang lain. Uji homogenitas varian dilakukan pada pretest dan posttest kelompok eksperimen dan kelompok kontrol.

Syarat data dikatakan bersifat homogen apabila nilai signifikansi hitung lebih besar dari taraf signifikansi, yaitu sebesar 0,05 $(p>0,05)$. Proses perhitungan dilakukan dengan bantuan komputer menggunakan program SPSS versi 22. Berikut disajikan rangkuman uji homogenitas varian data pretest dan posttest.

Tabel 6. Rangkuman Hasil Uji Homogenitas Pretest dan Posttest

\begin{tabular}{llllll}
\hline \multicolumn{1}{c}{ Data } & $\begin{array}{l}\text { Levene } \\
\text { Statistic }\end{array}$ & df1 & df2 & Sig & Keterangan \\
\hline skor pretest & 0,004 & 1 & 84 & 0,949 & Sig $>0,05=$ homogeny \\
\hline skor posttest & 3,330 & 1 & 84 & 0,072 & Sig $>0,05=$ homogeny \\
\hline
\end{tabular}

Tabel di atas menunjukkan hasil perhitungan data pretest siswa memperoleh Levene Statistic sebesar 0,004 dengan df1 sebesar 1 dan df 2 sebesar 84 serta taraf signifikansi sebesar 0,949. Data pretest kedua kelompok, baik kelompok eksperimen maupun kelompok kontrol dinyatakan homogen atau tidak memiliki perbedaan varian karena nilai signifikansinya lebih besar dari 0,05 $(0,949>0,05)$. Sementara itu, perhitungan data posttest diperoleh Levene Statistic sebesar 3,330 dengan df1 sebesar 1 dan df2 sebesar 84 serta taraf signifikansi sebesar 0,072 . Berdasarkan perhitungan tersebut dapat disimpulkan bahwa data posttest kedua kelompok, baik kelompok eksperimen maupun kelompok kontrol dikatakan homogen atau tidak memiliki perbedaan varian karena nilai signifikansinya lebih besar dari 0,05 $(0,072>0,05)$.

\section{c. Analisis Data}

1) Uji-t Data Pretest Pembelajaran Teks Prosedur Kompleks Kelompok Eksperimen dan Kelompok Kontrol

Uji-t data pretest dilakukan untuk mengetahui ada tidaknya perbedaan kemampuan memahami dan memproduksi teks prosedur kompleks yang signifikan antara kelompok eksperimen dengan kelompok kontrol sebelum diberi perlakuan. Rangkuman hasil uji-t pretest pembelajaran teks prosedur kompleks kelompok eksperimen dan kelompok kontrol dapat disajikan pada tabel berikut.

Tabel 7. Rangkuman Hasil Uji-t Pretest Pembelajaran Teks Prosedur Kompleks Kelompok Eksperimen dan Kelompok Kontrol

\begin{tabular}{lcccc}
\hline Data & $\mathrm{t}_{\mathrm{h}}$ & $\mathbf{d f}$ & $\begin{array}{l}\text { Sig }(2 \\
\text { tailed })\end{array}$ & Keterangan \\
\hline Pretest KE-KK & $-1,225$ & 43 & 0,224 & $\mathrm{p}>0,05 \neq$ signifikan \\
\hline
\end{tabular}


Tabel di atas menunjukkan bahwa berdasarkan perhitungan dengan menggunakan komputer dengan program SPSS versi 22 diperoleh nilai $\mathrm{t}$ hitung sebesar 1,225 dengan nilai df sebesar 43 dan signifikansi $(p)$ sebesar 0,224 pada taraf signifikansi 0,005 . Nilai $p$ lebih besar dari taraf signifikansi, dengan demikian hasil uji-t menunjukkan bahwa tidak ada perbedaan kemampuan memahami dan memproduksi teks prosedur kompleks antara kelompok eksperimen dengan kelompok kontrol sebelum diberi perlakuan.
2) Uji-t Data Posttest Pembelajaran Teks Prosedur Kompleks Kelompok Eksperimen dan Kelompok Kontrol

Uji-t data posttest dilakukan untuk mengetahui ada tidaknya perbedaan kemampuan memahami dan memproduksi teks prosedur kompleks yang signifikan antara kelompok eksperimen dengan kelompok kontrol sesudah diberi perlakuan. Rangkuman hasil uji-t posttest pembelajaran teks prosedur kompleks kelompok eksperimen dan kelompok kontrol dapat disajikan pada tabel berikut.

Tabel 8. Rangkuman Hasil Uji-t Posttest Pembelajaran Teks Prosedur Kompleks Kelompok Eksperimen dan Kelompok Kontrol

\begin{tabular}{lllll}
\hline Data & th & df & $\begin{array}{l}\text { Sig }(2 \\
\text { tailed })\end{array}$ & Keterangan \\
\hline Posttest KE-KK & $-2,575$ & 43 & 0,012 & $\mathrm{P}<0,05=$ signifikan \\
\hline
\end{tabular}

Berdasarkan tabel di atas diperoleh
hasil bahwa perhitungan dengan menggunakan bantuan komputer program SPSS 22 diperoleh nilai $t$ hitung sebesar 2,575 dengan nila df sebesar 43 dan nilai $p=0,012$ pada taraf signifikansi $0,05(5 \%)$. Nilai $p<$ dari taraf signifikansi $(0,012<$ $0,05)$ artinya hasil uji-t menunjukkan bahwa ada perbedaan yang signifikan kemampuan memahami dan memproduksi teks prosedur kompleks antara kelompok eksperimen dengan kelompok kontrol.
3) Uji-t Data Pretest dan Posttest Pembelajaran Teks Prosedur Kompleks Kelompok Eksperimen dan Kelompok Kontrol

Uji-t data pretest dan posttest pembelajaran teks prosedur kompleks kelompok eksperimen dan kelompok kontrol digunakan untuk mengetahui apakah media Laptop Si Unyil efektif digunakan dalam pembelajaran teks prosedur kompleks. Rangkuman hasil uji-t data pretest dan posttest pembelajaran teks prosedur kompleks kelompok eksperimen dan kelompok kontrol dapat dilihat pada tabel berikut.

Tabel 9. Rangkuman Hasil Uji-t Data Pretest dan Posttest Pembelajaran Teks Prosedur Kompleks Kelompok Eksperimen dan Kelompok Kontrol

\begin{tabular}{lllll}
\hline Data & $\mathrm{t}_{\mathrm{h}}$ & $\mathrm{df}$ & $\begin{array}{l}\text { Sig }(2 \\
\text { tailed })\end{array}$ & Keterangan \\
\hline Pretest-posttest $\mathrm{KK}$ & $-1,160$ & 42 & 0,253 & $\mathrm{p}>0,05 \neq$ signifikan \\
\hline Pretest-posttest $\mathrm{KE}$ & $-3,924$ & 42 & 0,000 & $\mathrm{p}<0,05=$ signifikan \\
\hline
\end{tabular}

Berdasarkan data pretest dan posttest pada kelompok kontrol di atas diperoleh hasil bahwa nilai $\mathrm{t}$ hitung $-1,160$ dengan nilai df 42 dan signifikansi 0,253 . Sementara itu, data pretest dan posttest pada kelompok eksperirmen diperoleh hasil bahwa nilai $\mathrm{t}$ hitung $-3,924$ dengan nilai df 42 dan signifikasi 0,000 . Hasil uji-t data pretest dan posttest pada kelompok eksperimen diperoleh nilai $p$ lebih kecil dari taraf signifikansi $0,05 \quad(0,000<0,05)$ dan hasil uji-t data pretest dan posttest kelompok 
kontrol diperoleh nilai $p$ lebih besar dari taraf signifikansi $0,005 \quad(0,253>0,05)$. Dengan demikian, hasil uji-t menunjukkan bahwa pembelajaran teks prosedur kompleks menggunakan media Laptop Si Unyil efektif digunakan.

\section{SIMPULAN}

Berdasarkan penelitian terhadap penggunaan media Laptop Si Unyil dalam pembelajaran teks prosedur kompleks dapat diperoleh hasil sebagai berikut.

1. Terdapat perbedaan kemampuan memahami dan memproduksi teks prosedur kompleks antara kelompok yang diajar dengan menggunakan media Laptop Si Unyil dengan kelompok yang diajar tanpa menggunakan media Laptop Si Unyil. Hal itu dapat dibuktikan dengan uji-t antar kelompok. Berdasar data posttest kelompok eksperimen dan kelompok kontrol diperoleh $\mathrm{t}$ hitung sebesar $-2,575$ dengan nila df sebesar 43 dan nilai $p=$ 0,012 pada taraf signifikansi 0,05 (5\%). Nilai $p<$ dari taraf signifikansi $0,05(0,012<0,05)$.

2. Media Laptop Si Unyil terbukti efektif digunakan dalam pembelajaran teks prosedur kompleks pada mahasiswa PBSI, FKIP, UAD yang sedang mengikuti mata kuliah Pembelajaran Bahasa Indonesia. Hal itu dibuktikan dari perhitungan uji-t data pretest dan posttest pada kelompok eksperimen diperoleh hasil bahwa nilai $\mathrm{t}$ hitung 3,924 dengan nilai df 42 dan signifikasi 0,000. Hasil uji-t data pretest dan posttest pada kelompok eksperimen diperoleh nilai $p$ lebih kecil dari taraf signifikansi 0,05 $(0,000<0,05)$.

3. Media Laptop Si Unyil dapat menjadi alternatif media pembelajaran teks prosedur kompleks pada siswa jenjang SMA karena guru dapat mengunduh dengan mudah di youtube.

\section{PERSANTUNAN}

Penulis mengucapkan terima kasih kepada Universitas Ahmad Dahlan yang sudah memberikan dukungan dana sehingga penelitian ini dapat berjalan dengan lancar dan mahasiswa PBSI, FKIP, UAD semester IV kelas A dan D yang mengikuti perkuliahan Pembelajaran Bahasa Indonesia tahun akademik 2016/2017 yang sudah menjadi sampel dalam penelitian ini.

\section{DAFTAR PUSTAKA}

Kosasih, E. 2014. Jenis-jenis Teks: Analisis Fungsi, Struktur, dan Kaidah serta Langkah Penulisannya. Bandung: Yrama Widya

Maryanto, dkk. 2013. Bahasa Indonesia Ekspresi Diri dan Akademik. Jakarta: Kemendikbud.

Priyatni, Endah Tri. 2015. Desain Pembelajaran Bahasa Indonesia dalam Kurikulum 2013. Jakarta: Bumi Aksara.

Sanjaya, Wina. 2012. Strategi Pembelajaran Berorientasi Standar Proses Pendidikan. Jakarta: Kencana.

Sulistiyono, Roni. 2016. "Laptop Si Unyil sebagai Alternatif Media Pembelajaran Teks Prosedur Kompleks". Ramly, dkk. (Ed). Proseding Seminar Nasional: Memperkukuh Peran APROBSI dalam Mewujudkan Kemitraan dan Pemberdayaan Program Studi Bahasa dan Sastra Indonesia yang Mandiri. Jakarta: Metabook. Hlm: 867-871

http://m.youtube.com/watch?v=Jxq0DCW 7laU) 